\title{
MEMBUMIKAN ILMU KOMUNIKASI DI INDONESIA (PEMBACAAN HERMENEUTIK GADAMERIAN ATAS TULISAN- TULISAN M. ALWI DAHLAN)
}

\author{
Winartono, Antoni, Anang Sujoko \\ Fakultas Ilmu Sosial dan Ilmu Politik Universitas Brawijaya \\ Email: putramulya.win@gmail.com, ant_ui@yahoo.com, anangsujoko@gmail.com
}

\begin{abstract}
:
The emergence of Communication Science in Indonesia was related to the history of this science in Europe and America. The term "communication science" (America's tradition) was noted to have replaced "Publisistic" (German's tradition). M. Alwi Dahlan is an important figure behind that. Communication Science then has been developing, but still dominated by applied studies. Whereas to be a discipline, the study of history and philosophy of science shouldn't be ignored. Furthermore, the development of a science indicates the contribution of it's intellctuals. Here is the importance of studying Dahlan's thoughts on communication. The researcher applied a Gadamerian perspective hermeneutic to interpret Dahlan's writings between 1980-1990s. Based on metanarrative awareness and the spirit of non-Western perspective studies, the researcher has explored them through hermeneutic circle until getting creative meanings (Bildung). The conclusion is that Dahlan's contribution is contextualizing or bringing Communication Science 'down to earth' in Indonesia especially related to development, environment, information-technology, through an eclectic perspective and by which human being as a key resource. Dahlan's ideas has significance in the development of history and philosophy of Communication Science. Finally, this research suggest further exploration both on Dahlan and related topics.
\end{abstract}

Key Words: M. Alwi Dahlan, Hermeneutics, Gadamerian Perspective, Ilmu Komunikasi

\begin{abstract}
Abstrak:
Munculnya Ilmu Komunikasi di Indonesia berkaitan erat dengan sejarah sejarah ilmu tersebut di Eropa dan Amerika. Istilah "Ilmu Komunikasi" (dalam tradisi Amerika) tercatat telah mengganti "Ilmu Publisistik" (tradisi Jerman). M. Alwi Dahlan adalah salah satu sosok penting dibalik pergantian tersebut. Kemudian Ilmu Komunikasi mengalami perkembangan, tetapi masih didominasi dengan kajian-kajian terapan. Padahal untuk menjadi disiplin ilmu yang kuat, kajian sejarah dan filsafat ilmu tidak bisa dikesampingkan. Lebih lanjut, perkembangan sebuah ilmu mengindikasikan kontribusi para intelektual di dalamnya. Di sinilah menjadi penting untuk mengkaji pemikiran M. Alwi Dahlan terkait Ilmu Komunikasi. Peneliti menggunakan sebuah pembacaan hermeneutik perspektif Gadamerian untuk menginterpretasi tulisan-tulisan M. Alwi Dahlan antara tahun 1980-1990an. Berangkat dari kesadaran metarnarasi dan semangat kajian perspektif non-Western, peneliti melakukan eksplorasi melalui proses lingkarhermeneutik dan pemahaman horizon-horizon, sehingga menghasilkan makna kreatif (Bildung). Melalui analisis sirkular berkelanjutan (part-whole, whole-part) dan disertai dengan upaya goodness criteria, maka diperoleh simpulan bildung, bahwa: kontribusi
\end{abstract}


(utama) M. Alwi Dahlan adalah membumikan Ilmu Komunikasi di Indonesia terutama terkait pembangunan, lingkungan, teknologi-informasi, melalui perspektif nalar eklektik dengan manusia sebagai sumberdaya kunci. Gagasan-gagasannya mempunyai arti penting dalam perkembangan sejarah dan filsafat Ilmu Komunikasi di Indonesia. Akhirnya dengan keterbatasannya, penelitian ini menyarankan upaya eksplorasi lanjut baik mengenai M. Alwi Dahlan maupun topik terkait lainnya.

Kata kunci: M. Alwi Dahlan, Hermeneutika, Perspektif Gadamerian, Ilmu Komunikasi.

\section{Pendahuluan}

Perubahan istilah "Ilmu Publisistik" menjadi "Ilmu Komunikasi" di Indonesia mengindikasikan (dominasi) mass communication, tradisi Amerika (Antoni, 2004). Hal ini tentu mempunyai konsekuensi-konsekuensi terhadap orientasi studi (Budi S, 2012). M. Awli Dahlan-sebagai tokoh generasi awal orang Indonesia yang belajar kajian komunikasi-menjadi seorang figur kunci dalam sejarah Ilmu Komunikasi di Indonesia. Tetapi meski demikian, perkembangan Ilmu ini terjadi dalam sisi kuantitas (studi) dan sangat didominasi dengan penelitian/kajian terapan. Di satu sisi, di Indonesia literature mengenai kajian ilmu komunikasi masih terbilang sedikit, padahal bidang kajian ilmu komunikasi telah berkembang cukup lama (Mulyana, 2013).

Untuk mengimbangi problem tersebut di atas, penelitian atau kajian teoritis terkhusus yang terkait dengan bidang kajian sejarah dan filsafat ilmu. Di sisi ini lah, kajian tentang pemikiran M. Alwi
Dahlan (dan topik serupa tentunya) semenjadi upaya yang bersifat mendesak untuk dilakukan. Setidaknya kajian ini berpeluang menjadi kontribusi akademis dan menjadi penyeimbang riset praktis yang dominan sejurus dengan jumlah program studi ilmu komunikasi di Indonesia.

Kajian tentang pemikiran tokoh juga telah muncul di tradisi akademik Barat, misalnya kupasan mengenai Lazarsfeld (Katz, 1987), McLuhan-Innis (Buxton, 2012), Carey (Ross, 2013), dan Schramm (McAnany, 2014). Sedangkan dalam kasus Indonesia, kajian-kajian semacam itu masih terbatas dan sangat perlu dikembangkan. Sebagai upaya awal, paper ini akan berfokus pada eksplorasi pemikiran M. Alwi Dahlan tentang Ilmu Komunikasi di Indonesia.

Dengan maksud eksplorasi tersebut paper (kajian) ini berupaya untuk memahami gagasan-gagasan M. Alwi Dahlan, factor-faktor yang mempengaruhi, dan perspektif yang mempunyai efek 
penting dalam konteks sejarah dan filsafat Ilmu Komunikasi.

\section{Pokok Materi dan Metode}

Berdasarkan paradigm interpretif, kajian ini menggunakan metode pembacaan hermeneutik perspektif

Gadamerian. Preferensi atas metode ini utamanya didasarkan pada pertimbangan hermeneutik atas aspek representasi. Menurut Lindlof \& Taylor (2002) aksi social data dilihat "from the actors point of view”. Selanjutnya, sebagai sebuah pemahaman (verstehen), fungsi representasi-baik yang berupa perspektif atau gagasan-gagasan pengarang-juga bisa melekat pada teks.

Dengan kata lain, fungsi representasi tersebut merujuk pada apa yang Haryatmoko. (2016) sebut sebagai "autonomisasi teks", yaitu (aspek) yang melepaskan teks dari konteks produksi dan 'dunia' penulis (author's intention). Jadi, metode ini menjadi tepat untuk menggali pemahaman actual tentang materi-materi, yang kesemuanya adalah berupa teks-teks tertulis.

Secara teknis, proses pemahaman berjalan melalui dialog dengan kemungkinan horizon-horizon penulis yang luas (Hardiman, 2015), yang itu terrepresentasi dalam teks. Kemudian, teks-teks tersebut dikembangkan dalam proses pemahaman lebih lanjut, utamanya mengenai bagaiman bagian-bagian (parts) teks berhadapan dengan keselurah (the whole). Proses ini dilakukan secara berkesinambungan melalui dialog data dan lingkar hermeneutic (Patton, 2002).

\section{Data dan Analisis}

Sebagai sebuah upaya eksplorasi awal, pengumpulan data dalam kajian ini menggunakan teknik dokumentasi, yang oleh Creswell (2014) dan Sloan \& Bowe (2013) dirujukkan sebagai satu opsi teknis dalam penelitan kualitatif.

Data yang dianalisis dalam paper ini adalah tulisan-tulisan M. Alwi Dahlan mengenai Ilmu Komunikasi dan topik yang terkait. Adapun batasan-batasan dalam kajian ini adalah pada tulisantulisan M. Alwi Dahlan utamanya yang terbit antara tahun 1980 hingga 1990an. Utamanya adalah sebagai berikut:

- 1982. Communication Research for policy-makers and planners: some preliminary observation. AMIC.

- 1983. Communication and change in Indonesia: an overview. AMIC.

- $\quad$ 1984. In search of the social meaning of communication satellites. AMIC.

- 1985. Report on a pilot study in environmental communication. AMIC.

- 1986. The Palapa project and rural development in Indonesia. AMIC. 
- 1986. Environmental communication: communicating the dilemma of development. AMIC.

- 1987. The Indonesian experience in social marketing. AMIC.

- 1989. The environmental orientation: an alternative approach in mass media coverage. AMIC.

- 1994. Expanding the role of media in environmental protection. AMIC.

- 1995. Information, technology, and society. AMIC.

- 1995. Bridging the socio-economic gap through new information technology. AMIC.

- 1997. Pemerataan informasi, komunikasi dan pembangunan. FISIP UI.

- 1997. Transformasi sosial abad XXI:

Tantangan teknologi, komunikasi dan informasi. BP-7.
- 1999. Information technology: enhancing or limiting democracy in Asia?. AMIC.

- 1999. Reformasi and the changing mediascape: implications of media liberalization. AMIC

Analisis data dilakukan dengan cara membaca (memahami) setiap teks. Proses pemahaman terdiri dari langkah-langkah pembacaan serius (scrutinizing) yang berkelanjutan: description-condensationreflection. Proses ini dilakukan dalam kerangka kerja lingkar hermeneutic (hermeneutic circle). Sebagai ilustrasi sederhana, berikut adalah sebuah diagram (flowchart) yang membantu memahami proses analisis dalam lingkar hermeneutik (Ghasemi, dkk, 2011).

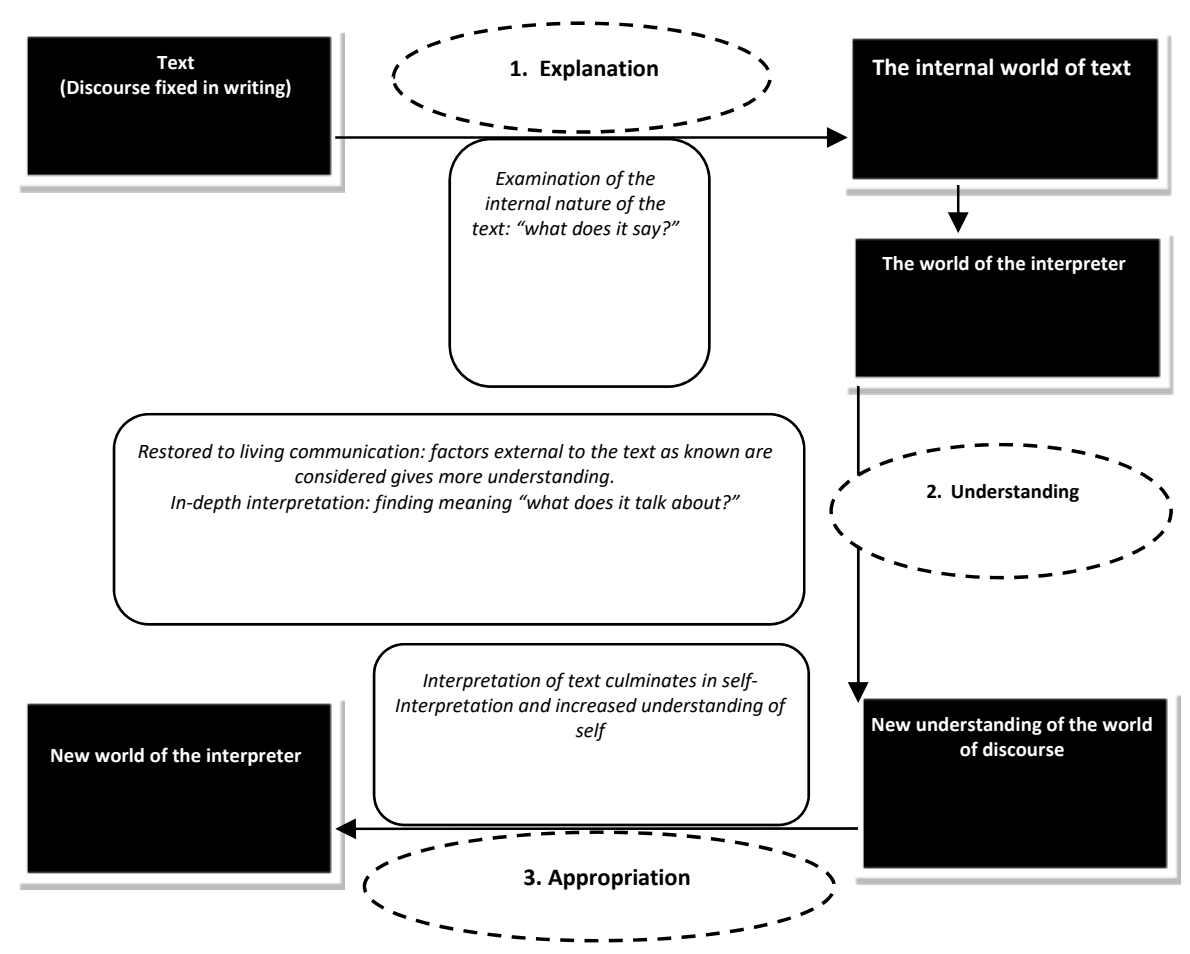




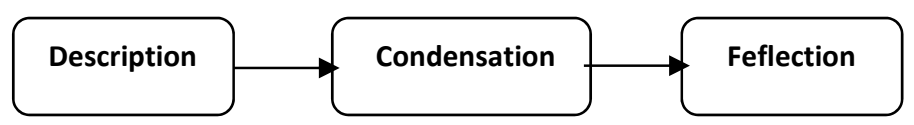

Sedangkan, berikut adalah deskripsi yang

Lebih lanjut lagi, untuk memperolehi

lebih sederhana dari pada alur di atas:

Untuk kriteria yang baik, seorang peneliti mengevaluasi relasi antara temuan dengan permasalahan kajian berdasarkan prinsip yang sesuai pada penelitian kualitatif; dari kepercayaan (credibility), kemungkinan tersampaikan (transferability), terpercaya (dependa-bility), dan hingga pada prinsip ketegasan / ketetapan (confirmability). Lebih lanjut, sebagai upaya prosedur yang rigid, menurut (Bradley, 1993) secara mendasar tahap ini dapat disederhanakan menjadi sebuah pembuktian yang praktis, yang cukup mengindikasikan bahwa penelitian/kajian bisa dilakuan dengan tulus: "carried out fairly" tanpa kelicikan/rekayasa.

Dalam penelitian kualitatif, keterpercayaan (trustworthiness) memerlukan adanya kesesuaian terhadap perspektif yang dipilih. Dalam hermeneutik perspektif Gadamerian, ke empat kriteria tersebut di atas dapat digantikan atau dicakup dalam dua prinsip dalam hermeneutik: hermeneutic circle dan fusion of horizons. Secara teknis, untuk mendapatkan hasil pemaknaan (Bildung) yang baik, peneliti berbagi atas temuan-temuan pada sejumlah peneliti yang (sedang) meneliti topik terkait. trustworthiness, temuan-temuan juga dipresentasikan dalam forum seminar akademik yang ber-peserta banyak. Paper ini adalah sebuah hasil yang telah melewati goodness criteria tersebut. Temuantemuan kajian telah dipresentasikan dalam acara seminar mengenai pemikiran $\mathrm{M}$. Alwi Dahlan dan kontribusinya dalam perkembangan Ilmu Komunikasi di Indonesia. Melalui forum berbagi tersebut, peneliti mendapatkan penilaian (assessment) dan masukan saran dari para hadirin. Dan beruntung sekali, hasil dari penilaian dan masukan mereka tidak ada penolakan yang signifikan atas temuan.

\section{Hasil dan Pembahasaan}

\section{Perspektif Elektik}

Dari pembacaan hermeneutik Gadamerian, proses interpretasi terhadap data yang terkumpul menghasilkan beberapa temuan. Di antaranya, peneliti menemukan petunjuk kunci dari gaya tulisan M. Alwi Dahlan. Ada persamaan pola atau logika penalaran yang digunakan dalam tulisan-tulisannya. Peneliti menyebutnya sebagai perspektif eklektik. Dengan perspektif tersebut lah M. Alwi Dahlan mendasari opini-opininya dalam tulisan. 
Perspektif eklektik disini mempunyai arti bahwa pendapat-pendapat M. Alwi Dahlan dalam studi Ilmu Komunikasipada saat itu-didasarkan pada aspek kebermanfaatan dari macam sumber mana pun. Dengan penjelasan lain, M. Alwi Dahlan melakukan adopsi dari apa pun sumbernya, dengan catatan bisa diambil manfaat. Sehingga dia cenderung untuk tidak memilih sikap kontradiksi atau sepenuhnya tidak setuju terhadap pendapat-pendapat atau teori-teori lain. Kesemuanya dapat dimanfaatkan untuk kebutuhan dan kepentingan tertentu, semisal untuk kepentingan kesatuan nasional, perluasan pemerataan pembangunan, dan pembentukan kondisi harmoni.

Mengenai perspektif eklektik, Hunter (1980) menyebut Chicago Schoolkhususnya di era awal munculnya communication studies-juga memilih perspektif tersebut. Penggunaan cara (perspektif) demikian bisa membantu menjawab permasalahan yang muncul: "would help ameliorate existing social problems." Lebih lanjut lagi, sebagaimana penjelasan tersebut, lanjut Hunter bahwa "the eclecticism of the theory and the research was more often the outcome of a pragmatic attempt to define clearly the social problems of the day and to propose a series of alternative solutions."

Dengan mengambil satu hal dengan hal lainnya, orientasi M. Alwi Dahlan mengarah pada pemberian solusi dan mereduksi efek-efek negatif. Konsistensi dalam memanfaatkan potensi dari sumber manapun sangat terlihat dalam tulisantulisannya. Dia selalu menganggap tiaptiap faktor mempunyai potensi yang bagus untuk kemudian dirumuskan menjadi jawaban atas kebutuhan pembangunan nasional atau prioritas Indonesia lainnya. Adapun pertimbangannya yang mendasar dari tindakan eklektik tersebut adalah kondisi lokal bangsa sebagai negara yang sedang berkembang pada saat itu.

Tulisan-tulisannya menunjukkan bahwa dia selalu berhati-hati dalam menyampaikan ide-ide atau opininya. Justru dia terlihat dalam tulisan-tulisannya, selalu berusaha menghindari konfrontasi atau kontradiksi antara teori dan faktor lainnya. Di setiap akhir tulisannya, dia biasanya menggunakan solusi penengah. Sikap seperti itu diterapkan oleh M. Alwi Dahlan dalam manyampaikan gagasangagasannya.

Dalam tulisan-tulisannya yang terbit antara tahun 1980-1990an, M. Alwi Dahlan sangat memperhatikan beberapa tema dan masalah terkait yang muncul. 
Adapun tema-tema perhatiannya tersebut di antaranya adalah: Komunikasi Pembangunan, Komunikasi Lingkungan, Komunikasi dan Teknologi (Informasi). Perspektif eklektik digunakan juga dalam mendiskusikan tema-tema tersebut dalam tulisan-tulisannya.

Terkait masalah komunikasi pembangunan, M. Alwi Dahlan tidak semerta-merta membela program pemerintah di satu sisi, dan di sisi lain menganggap masyarakat (budaya) sebagai sumber problem, meski pada saat itu dia adalah bagian dari pemerintahan. Dia berpendapat, misalnya, bahwa pemerintah seharusanya terus melakukan improvisasi program dalam upaya pembangunan nasional dan tanpa mengabaikan sumber daya manusia. Sikapnya yang demikian jga diterapkan dalam tema-tema tulisannya yang lain. Dia tidak berkecendungan untuk memposisikan beberapa element kontradiksi satu sama lain, misalnya antara: Pembangunan (infrastruktu) dengan aspek sosial dan keberlanjutan lingkungan hidup; teknologi informasi dan sumber daya manusi; dan dunia akademik (kampus) dengan dunia kerja praktisi (lapang). Masing-masing menurut $\mathrm{M}$. Alwi Dahlan mempunyai keunggulan, sehingga yang terpenting adalah bagaimana kesemua unggulan itu dirumuskan menjadi solusi terapan.

\section{Membumikan Ilmu Komunikasi}

Makna penting lainnya dari pemikiran M. Alwi Dahlan adalah upayanya untuk mengembangkan Ilmu Komunikasi di Indonesia. Dari tulisan-tulisannya tersebut di atas, dia menganggap komunikasi (informasi) sebagai sebuah kebutuhan sehari-hari kehidupan manusi. Lebih lanjut, dia menganggap bahwa Ilmu Komunikasi sama pentingnya dengan komunikasi itu sendiri, yang sudah melekat bahkan sejak awal kehidupan manusia.

Penelitian atau kajian komunikasi, dengan demikian, dapat menjadi sebuah instrumen bagi prioritas tertentu. M. Alwi Dahlan terlihat dalam tulisan-tulisannya sedang mencoba membawa Ilmu Komunikasi sebagai sebuah solusi bagi kondisi local Indonesia. Ide-idenya ditujukan pada kebutuhan nasional dan masyarakat. Dengan ungkapan lain, ideidenya adalah:

- Ilmu Komunikasi untuk Pemerataan Pembangunan

- Ilmu Komunikasi untuk Kelangsungan Lingkungan Hidup

- Ilmu Komunikasi untuk Stabilitas / integritas Nasional 
- Ilmu Komunikasi untuk Mengawal Transformasi

Secara umum, temuan lainnya dari pemikiran M. Alwi Dahlan adalah bahwa mengembangkan Ilmu Komunikasi dapat dilakukan melalui penelitian/kajian atas beberapa topic yang terkait dengan kebutuhan. Dengan spirit pragmatism, M. Alwi Dahlan berusaha untuk membumikan Ilmu Komunikasi di Indonesia. Sehingga dengan demikian, Ilmu Komunikasi dapat difungsikan

untuk menjawab/memecahkan masalah yang ada. Oleh karena itu, Ilmu tersebut menjadi benar-benar bermanfaat bagi kehidupan sehari-hari-bukan menjadi ilmu yang tidak membumi (utopian science). Tindakan/sikap ini juga merefleksikan upaya Bapak Ilmu Komunikasi Indonesia ini untuk mengeksplorasi perspektif nonwestern dalam Ilmu Komunikasi.

\section{Kesimpulan}

Singkat penjelasan, melalui paper (kajian) eksploratif tentang Pemikiran M.

Alwi Dahlan dengan menggunakan perspektif hermeneutik Gadamerian ini, akhirnya peneliti mencoba untuk memberi beberapa simpulan temuan. Simpulan temuan tersebut tidak lain adalah-apa yang dalam hermeneutika Gademerian disebut_actual meaning (Bildung) terkait
Ilmu Komunikasi. Berikut adalah beberap temuan tersebut:

1). Dalam menyampaikan ide-idenya tentang komunikasi, M. Alwi Dahlan lebih memilih perspektif eklektik dari pada memilih cara yang kritis-konfrontatif.

2). Tema-tema utama yang menjadi perhatian M. Alwi Dahlan dalam tulisannya (1980-1990an) adalah "Komunikasi Pembangunan", "Komunikasi Lingkungan", dan "Informasi dan Teknologi Informasi".

3). Hakikat (aktivitas) komunikasi adalah informasi.

4). Meskipun teknologi (informasi) mengalami perkembangan yang cepat, $\mathrm{M}$. Alwi Dahlan masih mempertimbangkan sisi manusi (Sumber Daya Manusia) sebagai subjek penentu.

5). Secara umum dan dalam konteks Ilmu Komunikasi, apa yang telah dilakukan (ditulis) oleh M. Alwi Dahlan adalah dalam rangka "Membumikan Ilmu Komunikasi di Indonesia".

Akhirnya, kontribsi M. Alwi Dahlan adalah MEMBUMIKAN ILMU KOMUNIKASI DI INDONESIA, terutama terkait Pembangunan, Lingkungan, Teknologi Informasi, melalui perspektif (nalar) eklektik dengan Manusia sebagai sumberdaya kunci. Dari proses pembacaan tersebut, paper ini ingin 
menegaskan bahwa fenomena dan gagasan M. Alwi Dahlan mempunyai arti sangat penting dalam perkembangan sejarah dan filsafat Ilmu Komunikasi di Indonesia.

Paper (kajian) ini tentu tidak terlepas dari kekurangan, baik pada keluasan data (atau horizon pemahaman), kurang rigidnya metodologi, maupun pada aspek lainnya. Berangkat dari pengandaian hermeneutic perspektif Gadamerian hasil temuan kajian (Bildung) tersebut di atas pada hakikatnya adalah dalam kondisi 'selalu bergerak dalam sejarah' (Hardiman, 2015). Hal ini berarti membutuhkan penelusuran makna (verstehen) lebih lanjut. Sehingga luasnya horizon pemaknaan akan semakin melengkapi bildung mengenai subjekutamnya dalam hal ini: M. Alwi Dahlan dan perkembangan Ilmu Komunikasi di Indonesia.

\section{Daftar Pustaka}

Antoni. 2004. Riuhnya Persimpangan itu: Profil dan pemikiran para penggagas kajian ilmu komunikasi. Tiga Serangkai. Solo.

Bradley, J. 1993. Methodological Issues and Practices in Qualitative Research. The Library Quarterly: Information, Community, Policy, Vol. 63, No. 4, Symposium on
Qualitative Research: Theory, Methods, and Applications. The University of Chicago Press, 431449.

Budi, S. 2012. Communication Review; Catatan tentang Pendidikan Komunikasi di Indonesia, Jerman dan Australia. Program Studi Ilmu Komunikasi Universitas Atma Jaya, ASPIKOM dan Buku Litera. Yogyakarta

Buxton, W. J. 2012. The Rise of McLuhanism, The Loss of Innissense: Rethinking the Origins of the Toronto School of Communication. Canadian Journal of Communication Concordia University. Complete page 577.

Creswell, J. W. 2014. Penelitian kualitatif dan desain riset: memilih di antara 5 pendekatan (edsi ke 3). Pustaka Pelajar.

Dahlan, M. A. 1982. Communication Research for policy-makers and planners: some preliminary observation. AMIC.

1983. Communication and change in Indonesia: an overview. AMIC.

------. 1984. In search of the social meaning of communication satellites. AMIC. 
Dahlan, M. A., Chu, G. C., \& Jamieson, N. L. 1985. Report on a pilot study in environmental communication. AMIC.

Dahlan, M. A. 1986. The Palapa project and rural development in Indonesia. AMIC.

-----. $\quad 1986 . \quad$ Environmental communication: communicating the dilemma of development. AMIC.

------. 1987. The Indonesian experience in social marketing. AMIC.

------. 1989. The environmental orientation: an alternative approach in mass media coverage. AMIC.

------. 1994. Expanding the role of media in environmental protection. AMIC.

------. 1995. Information, technology, and society. AMIC.

------. 1995. Bridging the socio-economic gap through new information technology. AMIC.

------. 1997. Pemerataan informasi, komunikasi dan pembangunan. FISIP UI.

------. 1997. Transformasi sosial abad XXI: Tantangan teknologi, komunikasi dan informasi. BP-7.

------. 1999. Information technology: enhancing or limiting democracy in Asia? AMIC.
1999. Reformasi and the changing mediascape: implications of media liberalization. AMIC.

Ghasemi, A., Taghinejad, M., Kabiri, A., \& Imani, M. 2011. Ricoeur's Theory of Interpretation: A Method for Understanding Text (Course Text). World Applied Sciences Journal. 1623-1629.

Hardiman, F. B. 2015. Seni Memahami; Hermeneutik dari Schleiermacher sampai Derrida. Penerbit PT. Kanisius. Yogyakarta

Haryatmoko. 2016. Membongkar Rezim Kepastian; Pemikiran Kritis PostStrukturalis. PT. Kanisius. Yogyakarta.

Hunter, A. 1980. Why Chicago? The Rise of the Chicago School of Urban Social Science. The American Behavioral Scientist. ABI/INFORM Collection, 215.

Katz, E. 1987. Communications Research Since Lazarsfeld. Penn libraries University of Pennsylvania.

Lindlof, T. R., \& Taylor, B. C. 2002. Qualitative Communication Research Methods (scond edition). SAGE Publication Inc.

McAnany, E. G. 2014. Wilbur Schramm: Beginnings of the "Communication" 
Field. Communication Research Ross, M. 2013. An Alternative Path: The Trends. Volume 33.

Mulyana, D. 2013. Peluang mengembangkan kajian komunikasi. Intellectual Legacy of James $W$. In U. Saefullah, Kapita selekta Carey. Master's thesis. Retrieved from

komunikasi, pendekatan budaya dan http://scholarcommons.sc.edu/etd/1 504. agama. p. iv. Simbiosa Rekatama Media. Bandung

Patton, M. Q. 2002. Qualitative Research \& Evaluation Methods (3rd edition). Sage Publication, Inc. California.
Sloan, A., \& Bowe, B. 2013. Phenomenology and Hermeneutic Phenomenology: the Philosophy, the Methodologies, and Using Hermeneutic Phenomenology to Investigate Lecture's Experiences of Curriculum Design. Springer Science + Business Media Dordrecht. 1291-1303. 